\title{
ANALISIS KINERJA KEUANGAN PERUM BULOG SELAMA PENUGASAN PUBLIC SERVICE OBLIGATION TAHUN 2015-2018
}

I Putu Restu Krisnawan ${ }^{1}$ dan Ambang Aries Yudanto ${ }^{2}$

${ }^{1), 2}$ Jurusan Manajemen Keuangan, Politeknik Keuangan Negara STAN

Alamat Korespondensi: restukrisnawaniputu@gmail.com, ariesyudanto@pknstan.ac.id

\begin{abstract}
INFORMASI ARTIKEL ABSTRAK

Diterima Pertama

[ 28 Mei 2021]

Dinyatakan Diterima

[26 Juni 2021]

KATA KUNCl:

PSO, Kinerja Keuangan, Rasio Keuangan

The objective of this research is to analyze financial performance of Perum BULOG when receiving PSO during 2015-2018 using financial statement review and financial ratio analysis proxied by liquidity ratio, solvability ratio, activity ratio, and profitability ratio. The data used are secondary data in form of financial reports and complemented by field research through interview process. The combination method is used in data analysis process to make a conclusion from numbers into descriptive analysis. The results showed a decrease in sales performance and an increase in company's financial burden. Liquidity and solvability ratio are in good condition, activity ratio fluctuates, and there was a downward trend in profitability ratio. The suggestion from this research is that Perum BULOG needs to control the inventory, short-term liability, and optimize the commercial segment.
\end{abstract}

Tujuan penelitian, yaitu untuk menganalisis kinerja keuangan Perum BULOG selama menerima penugasan PSO pada tahun 2015-2018 melalui tinjauan terhadap laporan keuangan dan analisis rasio yang diproksikan dengan rasio likuiditas, solvabilitas, aktivitas, dan profitabilitas. Data yang digunakan adalah data sekunder berupa laporan keuangan dan laporan tahunan yang dilengkapi dengan penelitian lapangan melalui proses wawancara. Metode analisis data menggunakan metode kombinasi untuk menyimpulkan data berupa angka menjadi analisis deskriptif. Hasil penelitian menunjukkan penurunan kinerja penjualan dan peningkatan beban keuangan perusahaan. Rasio likuiditas dan solvabilitas berada dalam kondisi baik, rasio aktivitas mengalami fluktuasi, dan adanya trend penurunan pada rasio profitabilitas. Saran dari penelitian ini adalah Perum BULOG perlu melakukan kontrol pada persediaan, liabilitas jangka pendek, dan optimalisasi segmen komersial. 
ANALISIS KINERJA KEUANGAN PERUM BULOG SELAMA PENUGASAN PUBLIC SERVICE OBLIGATION TAHUN 2015 - 2018

I Putu Restu Krisnawan ${ }^{1}$ dan Ambang Aries Yudanto ${ }^{2}$

\section{PENDAHULUAN}

Salah satu hal fundamental untuk mewujudkan kesejahteraan sosial bagi masyarakat suatu negara adalah dengan mewujudkan ketahanan pangan dalam negeri. Menurut UU No. 18 Tahun 2012 tentang Pangan, ketahanan pangan merupakan kondisi terpenuhinya pangan bagi negara sampai dengan perseorangan, yang tercermin dari tersedianya pangan yang cukup, baik jumlah maupun mutunya, aman, bergizi, merata, dan terjangkau, serta tidak bertentangan dengan agama, keyakinan, dan budaya masyarakat, untuk dapat hidup sehat, aktif, dan produktif secara berkelanjutan.

Sejauh ini, urusan ketahanan pangan di Indonesia ditangani oleh beberapa kementerian, seperti Kementerian Pertanian dan Kementerian Dalam Negeri, serta sebuah badan usaha milik negara (BUMN). UU No. 18 Tahun 2012 tentang Pangan menyatakan bahwa negara berkewajiban mewujudkan ketersediaan, keterjangkauan, dan pemenuhan konsumsi pangan yang cukup, aman, bermutu, bergizi seimbang, baik pada tingkat nasional maupun daerah hingga perseorangan secara merata di seluruh wilayah NKRI. Guna mewujudkan hal tersebut, pemerintah memerlukan kelembagaan yang mampu menangani bidang pangan untuk mewujudkan ketersediaan, keterjangkauan, serta pemenuhan pangan, terutama beras sebagai salah satu makanan pokok dari masyarakat Indonesia. Perum BULOG menjadi salah satu ujung tombak pemerintah dalam memastikan ketersediaan, terutama beras, dan keterjangkauan pangan kepada masyarakat. Didirikan pada tahun 1967, Perum BULOG merupakan salah satu BUMN berbentuk Perum yang memainkan peran besar dalam menjaga ketahanan pangan Indonesia. Perum BULOG menjalankan bisnis dalam lingkup usaha logistik/pergudangan, survei pemberantasan hama, penyediaan karung plastik, usaha angkutan, perdagangan komoditi pangan dan usaha eceran. Perum BULOG juga mengemban tugas publik guna menjaga harga dasar pembelian gabah, stabilisasi harga pokok, penyaluran beras untuk orang miskin (raskin) serta pengelolaan stok pangan (BULOG, 2019).
Jurnal Indonesia RICH, Vol. 2, No. 1, (2021), 15-31

Berdasarkan PP No. 13 Tahun 2016 tentang Perusahaan Umum (Perum) BULOG, pemerintah melanjutkan penugasan kepada Perum BULOG untuk melaksanakan tugas dan tanggung jawab dalam rangka ketahanan pangan nasional berupa pengamanan harga pangan pokok beras di tingkat produsen dan konsumen, pengelolaan cadangan pangan pokok beras pemerintah, penyediaan dan pendistribusian pangan pokok beras kepada golongan masyarakat tertentu, dan pelaksanaan impor beras. Jika dilihat dari fungsi strategis yang diembannya, Perum BULOG mendapat beberapa penugasan dalam rangka PSO (Public Service Obligation) dari pemerintah melalui penerapan beberapa regulasi sejak tahun 2015. Pemerintah mengeluarkan Inpres No. 5 Tahun 2015 tentang Kebijakan Pengadaan Gabah/Beras dan Penyaluran Beras oleh Pemerintah yang memandatkan Perum BULOG untuk melaksanakan kebijakan pengadaan dan penyaluran beras baik itu beras bersubsidi, maupun cadangan beras pemerintah (CBP) guna menjaga stabilitas harga. Adanya PSO tersebut mampu meningkatkan produktivitas hingga menyelamatkan Perum BULOG dari rantai kerugian yang dialami sejak tahun 2012. Perum BULOG memperoleh laba bersih komprehensif sebesar Rp931 miliar, meningkat dari rugi komprehensif yang dialami sebesar Rp459 miliar pada tahun 2014. Hal yang sama juga dialami pada tahun 2016 setelah penerbitan PP No. 48 Tahun 2016 tentang Penugasan Kepada Perusahaan Umum (Perum) BULOG Dalam Rangka Ketahanan Pangan Nasional yang menyebabkan Perum BULOG mencatatkan kinerja positif, seperti peningkatan operasional pengadaan beras yang naik dari semula 2.611.583 ton pada akhir tahun 2015 menjadi 3.510.101 ton pada akhir tahun 2016.

Namun, adanya PSO kepada Perum BULOG tidak serta merta meningkatkan performa dari kinerja keuangan perusahaan. PSO yang diberikan ternyata tidak mampu memberikan peningkatan performa yang berkelanjutan kepada Perum BULOG. PSO tersebut berimplikasi pada adanya utang dari pinjaman saat melakukan pengadaan. Pada proses pengadaan Perum BULOG akan melakukan pinjaman uang yang dikenakan bunga komersil. Oleh sebab itu, Perum BULOG harus bertahan menunggu penggantian dari pengadaan oleh 
ANALISIS KINERJA KEUANGAN PERUM BULOG SELAMA PENUGASAN PUBLIC SERVICE OBLIGATION TAHUN 2015 - 2018

I Putu Restu Krisnawan ${ }^{1}$ dan Ambang Aries Yudanto ${ }^{2}$

pemerintah yang melalui proses panjang untuk fase pencairan. Selain itu, proses penyaluran beras Perum BULOG juga masih menemukan hambatan, seperti penggelontoran CBP yang memerlukan rapat koordinasi terbatas sehingga membutuhkan waktu yang cukup panjang. Dampaknya, operasional Perum BULOG terhambat dan berimplikasi pada tertekannya kinerja keuangan perusahaan (Thomas, 2019).

Oleh karena itu penting bagi sebuah perusahaan untuk mengetahui kinerja perusahaan, salah satunya dengan pendekatan analisis rasio keuangan. Analisis ini penting untuk dilakukan karena untuk memahami laporan keuangan, identifikasi pengembangan dan kinerja perusahaan, serta mengukur situasi terkini terkait kondisi bisnis perusahaan (Rashid, 2018).
Dalam kasus BULOG, pada tahun 2018, kerugian kembali menghampiri kinerja keuangan. Laporan keuangan mencatat adanya rugi komprehensif sebesar Rp835 miliar pada tahun 2018 akibat meningkatnya beban keuangan. Hal tersebut memunculkan spekulasi terkait efektivitas dan efisiensi dari penugasan yang diberikan kepada Perum BULOG. Selain itu, berbagai pemangku kepentingan, seperti Ombudsman, juga mulai mempertanyakan kinerja dan performa Perum BULOG dalam melaksanakan tugasnya ketika kinerja keuangannya terus menunjukkan penurunan (Ristianto, 2019). Inkonsistensi terkait dampak pemberian PSO terhadap kinerja keuangan Perum BULOG tersebut dapat diamati pada Gambar I.

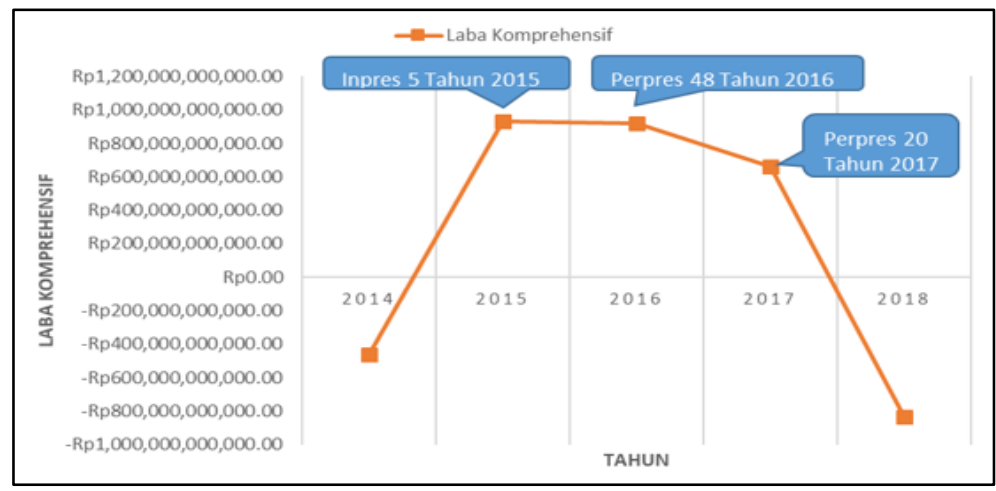

\section{Gambar I Laba Komprehensif Perum BULOG Tahun 2014-2018 Sumber: Data diolah Penulis}

Inkonsistensi kinerja ini juga terjadi pada beberapa subdivisi regional BULOG. Penelitian dari Nugraha (2019) menunjukkan kinerja keuangan BULOG pada tahun 2015-2017 divisi Regional Jawa Timur mengalami profitabilitas yang tidak stabil. Penelitian Ingan, et al (2020) pada BULOG Divisi Samarinda tahun 20162018 juga menunjukkan kecenderungan tendensi profitabilitas yang serupa. Dengan mempertimbangkan fenomena di atas, maka tujuan penelitian ini adalah untuk menganalisis kinerja keuangan Perum BULOG, khususnya pada tahun 2015-2018 saat beberapa PSO diberikan melalui tinjauan terhadap laporan keuangan dan analisis rasio keuangan. Analisis terhadap kinerja keuangan ini penting untuk mengetahui keberlanjutan PSO yang diberikan agar opsi pemberian PSO berikutnya dapat dikaji lebih mendalam oleh pembuat kebijakan.

\section{TINJAUAN TEORITIS \\ PSO (Public Service Obligation) terhadap Perum BULOG}

Secara kronologis, Pemerintah memberikan penugasan (PSO) kepada Perum BULOG sesuai dengan Pasal 6 ayat (2) huruf b PP No. 7 Tahun 2003 tentang Pendirian Perum BULOG, yakni maksud dan tujuan didirikannya Perum BULOG adalah "dalam hal tertentu melaksanakan tugastugas tertentu yang diberikan pemerintah dalam pengamanan harga bahan pangan pokok, pengelolaan cadangan pangan pemerintah dan distribusi pangan pokok kepada golongan masyarakat tertentu, khususnya pangan pokok 
ANALISIS KINERJA KEUANGAN PERUM BULOG SELAMA PENUGASAN PUBLIC SERVICE OBLIGATION TAHUN 2015 - 2018

I Putu Restu Krisnawan ${ }^{1}$ dan Ambang Aries Yudanto ${ }^{2}$

lainnya yang ditetapkan pemerintah dalam rangka ketahanan pangan. Hal tersebut selanjutnya dipertegas dengan Inpres tentang Kebijaksanaan Perberasan yang diperbaharui secara rutin. PP No. 7 Tahun 2003 inipun pada akhirnya dinyatakan dicabut dan tidak berlaku, seiring dengan dikeluarkannya PP No. 13 Tahun 2016 tentang Perusahaan Umum (Perum) BULOG.

Selama tahun analisis, yakni 2015-2018, terdapat beberapa penugasan yang diberikan kepada Perum BULOG. Secara kronologis, penugasan tersebut adalah Inpres No. 5 Tahun 2015, Perpres No. 48 Tahun 2016, dan Perpres No. 20 Tahun 2017.

a. Inpres No. 5 Tahun 2015

Peraturan ini ditetapkan pada tanggal 17 Maret 2015 dan penetapannya mencabut Inpres No. 3 Tahun 2012 tentang Kebijakan Pengadaan Gabah/Beras dan Penyaluran Beras oleh Pemerintah. Penerbitan Inpres ini merupakan kelanjutan dari Kebijakan Perberasan dalam rangka mendukung stabilisasi perekonomian nasional, melindungi tingkat pendapatan petani, stabilisasi harga beras, pengamanan CBP, dan penyaluran beras untuk keperluan yang ditetapkan oleh pemerintah. Dengan berlakunya Inpres ini, ditetapkan bahwa pelaksanaan pengadaan melalui pembelian gabah/beras oleh pemerintah dilakukan oleh Perum BULOG. Hal ini juga termasuk pelaksanaan kebijakan pengadaan beras dari luar negeri. Selain itu, dalam rangka kebijakan pengadaan dan penyaluran beras, Perum BULOG juga menetapkan kebijakan pengadaan dan penyaluran beras bersubsidi bagi kelompok masyarakat berpendapatan rendah, serta menetapkan kebijakan pengadaan dan penyaluran CBP untuk menjaga stabilitas harga, menanggulangi keadaan darurat, bencana dan rawan pangan, bantuan dan/atau kerja sama internasional, serta keperluan lain yang ditetapkan oleh pemerintah. Inpres ini juga mengatur terkait ketentuan harga pembelian pemerintah yang terdiri dari harga pembelian gabah kering panen dalam negeri, harga pembelian gabah kering giling dalam negeri, dan harga pembelian beras dalam negeri. Masingmasing harga pembelian tersebut dibedakan berdasarkan kualitas kadar air dan kadar hampa/kotoran pada masing-masing produk.

\section{b. Perpres No. 48 Tahun 2016}

Peraturan ini ditetapkan pada tanggal $25 \mathrm{Mei}$ 2016 dan penetapannya secara langsung menugaskan Perum BULOG yang berdasarkan atas ketentuan Pasal 3 ayat 8 PP No. 13 Tahun 2016 tentang Perum BULOG dalam Rangka Ketahanan Pangan Nasional. Peraturan ini diterbitkan dalam rangka menjaga ketersediaan pangan dan stabilisasi harga pangan pada tingkat konsumen dan produsen. Perum BULOG ditugaskan untuk menjaga ketersediaan pangan dan stabilisasi harga untuk jenis pangan pokok beras, jagung dan kedelai.

\section{c. Perpres No. 20 Tahun 2017}

Perpres No. 27 Tahun 2017 tentang Perubahan atas Perpres No. 48 Tahun 2016 tentang Penugasan kepada Perusahaan Umum (Perum) BULOG dalam rangka Ketahanan Pangan Nasional ditetapkan pada tanggal 24 Februari 2017 sebagai salah satu langkah untuk mengantisipasi dampak kondisi iklim ekstrem yang dapat mengganggu penyerapan produksi gabah dan beras dalam negeri, memperkuat dan mempercepat persediaan beras, serta stabilisasi harga beras pada tingkat konsumen dan produsen. Dalam regulasi ini, beberapa pasal disisipkan di antara Pasal 17 dan Pasal 18 PP No. 48 Tahun 2016. Beberapa kewenangan seperti terkait penetapan HPP, pelaksanaan impor, penggunaan cadangan pangan pemerintah untuk kekurangan pangan, serta pemberian kompensasi dan alokasi anggaran kepada Perum BULOG dilimpahkan kepada menteri yang menyelenggarakan urusan pemerintahan di bidang pertanian. Dalam aturan ini juga lebih ditegaskan terkait acuan HPP yang digunakan adalah sebagaimana yang diatur dalam Inpres No. 5 tahun 2015 dengan adanya fleksibilitas sebesar $10 \%$.

\section{Rasio Keuangan}

Rasio keuangan merupakan alat analisis keuangan perusahaan untuk menilai kinerja suatu perusahaan berdasarkan perbandingan yang terdapat pada pos laporan keuangan (Andriyani, 2015). Investor akan banyak bergantung pada analisis rasio keuangan untuk meneliti masa depan dari sebuah perusahaan berikut dengan kondisi keuangannya (Noreen, E. W., Brewer, P. C., \& Garrison, 2011). Rasio 
ANALISIS KINERJA KEUANGAN PERUM BULOG SELAMA PENUGASAN PUBLIC SERVICE OBLIGATION TAHUN 2015 - 2018

I Putu Restu Krisnawan ${ }^{1}$ dan Ambang Aries Yudanto ${ }^{2}$

keuangan yang digunakan adalah sebagai berikut.

a. Rasio Likuiditas

Rasio likuiditas menurut Kasmir (2012) merupakan rasio yang menggambarkan kemampuan perusahaan dalam memenuhi kewajiban jangka pendek. Likuiditas bisa dilihat sebagai konsep keuangan yang berarti terdapatnya dana yang bisa digunakan untuk investasi (Acharya, Viral V. and Afonso, Gara and Kovner, 2017). Rasio ini termasuk rasio yang paling krusial dalam mengetahui posisi keuangan sebuah perusahaan (Olaganju, A \& Adeyanju, D \& Olabode, 2011). Semakin tinggi rasio likuiditasnya maka investor melihat bahwa perusahaan ini sedang mengelola kas yang relatif banyak (Bolek \& Wolski, 2012). Rasio ini juga mengukur seberapa likuid aktiva lancar yang dimiliki oleh perusahaan tersebut sehingga dapat digunakan untuk melunasi utang jatuh tempo yang dimiliki.

1) Current ratio

Rasio ini mengukur seberapa banyak aktiva lancar yang tersedia untuk menutupi kewajiban jangka pendek yang akan jatuh tempo.

Rumus:

$$
\text { Current Ratio }=\frac{\text { Aktiva Lancar }}{\text { Hutang Lancar }} \times 100 \%
$$

Aktiva lancer disini terdiri dari kas dan setara kas (dimana bisa dikonversi menjadi kas dalam jangka waktu relatif pendek) (Boudoukh \& Whitelaw, 1993). Semakin tinggi hasil dari perhitungan rasio ini, maka perusahaan memiliki kemampuan yang semakin baik untuk menutupi kewajiban lancarnya. Jika hasil perhitungan di atas $100 \%$ maka perusahaan dianggap mampu melunasi kewajiban lancar tanpa mengganggu proses bisnis yang terjadi.

2) Quick ratio

Rasio ini menunjukkan kemampuan perusahaan untuk membayar kewajiban jangka pendek dengan aktiva lancar tanpa memperhitungkan aspek persediaan. Hal tersebut dikarenakan persediaan relatif lebih sulit untuk dicairkan menjadi kas.

Rumus:

$$
\begin{aligned}
& \text { Quick Ratio } \\
& =\frac{(\text { Aktiva Lancar }- \text { Persediaan })}{\text { Hutang Lancar }}
\end{aligned}
$$

Jika hasil perhitungan menunjukkan angka di atas 100\%, maka perusahaan dikatakan mampu untuk melunasi utang lancar yang dimiliki tanpa mengganggu proses bisnis.

3) Cash Ratio

Rasio ini mengukur seberapa besar uang kas yang tersedia untuk membayar utang jangka pendek. Kas dan kas ekuivalen tersebut dapat berupa dana kas, rekening giro, tabungan bank, serta setara kas lainnya.

Rumus:

$$
\text { Cash Ratio }=\frac{\text { Kas }}{\text { Hutang Lancar }} \times 100 \%
$$

Semakin besar nilai dari rasio ini, maka perusahaan dikatakan memiliki kemampuan yang tinggi untuk melunasi utang jangka pendek dengan kas yang dimilikinya.

b. Rasio Solvabilitas

Rasio solvabilitas merupakan rasio yang digunakan untuk mengukur sejauh mana aktiva perusahaan dibiayai dengan utang (Kasmir, 2003a).

1) Debt to equity ratio

Rasio ini mengamati seberapa besar ekuitas dari perusahaan yang digunakan sebagai jaminan pada setiap utang yang dimiliki oleh perusahaan.

Rumus:

Debt to Equity Ratio $=\frac{\text { Total Hutang }}{\text { Ekuitas }} \times 100 \%$

Semakin kecil hasil rasio ini menunjukkan kondisi perusahaan yang semakin baik. semakin tinggi persentasenya, maka perusahaan akan memiliki kemampuan yang semakin kecil untuk melunasi seluruh utangnya.

\section{2) Debt to Total Asset Ratio}

Rasio ini digunakan untuk mengukur perbandingan antara total utang dan total aktiva. Melalui rasio ini dapat diamati seberapa besar aktiva dari perusahaan yang dibiayai dengan utang.

Rumus:

Debt to Total Asset Ratio

$$
=\frac{\text { Total Hutang }}{\text { Total Aktiva }} \times 100 \%
$$

Semakin kecil hasil perhitungan menggambarkan kondisi perusahaan yang semakin baik sebab aset perusahan semakin sedikit yang dibiayai dengan utang.

c. Rasio Aktivitas 
ANALISIS KINERJA KEUANGAN PERUM BULOG SELAMA PENUGASAN PUBLIC SERVICE OBLIGATION TAHUN 2015 $-2018$

I Putu Restu Krisnawan ${ }^{1}$ dan Ambang Aries Yudanto ${ }^{2}$

Rasio ini merupakan rasio yang digunakan untuk mengukur tingkat efisiensi pemanfaatan sumber daya perusahaan (penjualan, persediaan, penagihan piutang, dan lain-lain) (Kasmir, 2003b).

\section{1) Total Assets Turnover}

Rasio ini digunakan untuk mengukur penggunaan semua aktiva perusahaan dalam rangka menghasilkan dan meningkatkan penjualan. Rasio ini juga menggambarkan berapa jumlah penjualan yang diperoleh dari setiap rupiah aktiva yang dimiliki.

Rumus:

Total Asset Turnover

Semakin tinggi hasil perhitungan menggambarkan efisiensi pengelolaan aktiva perusahaan yang semakin baik.

2) Fixed Assets Turnover

Rasio ini digunakan untuk mengukur berapa kali dana yang ditanamkan pada aset tetap berputar dalam suatu periode tertentu. Rasio ini juga menggambarkan seberapa efektif penggunaan aktiva tetap untuk melakukan kegiatan bisnis perusahaan.

Rumus:

\section{Fixed Asset Turnover}

$$
=\frac{\text { Penjualan Bersih }}{\text { Aktiva Tetap }} \times 1 \text { kali }
$$

Semakin besar hasil perhitungan menunjukkan penggunaan aset tetap yang optimal untuk proses bisnis perusahaan jika hasilnya kecil, maka dapat dikatakan aset perusahaan terlalu banyak namun tidak digunakan, atau telah digunakan namun belum maksimal.

\section{3) Inventory Turnover}

Rasio ini digunakan untuk mengetahui perputaran persediaan serta seberapa efektif perusahaan melakukan pengelolaan terhadap persediaannya.

Rumus:

$$
\text { Inventory Turnover }
$$

$$
\begin{aligned}
& =\frac{\text { Harga Pokok Penjualan }}{\text { Rata-rata Persediaan }} \\
& \times 100 \%
\end{aligned}
$$

Rata - rata Persediaan

$=\frac{(\text { Persediaan awal }+ \text { Persediaan Akhir })}{2}$
Semakin tinggi hasil perhitungan menggambarkan pengelolaan yang efektif terhadap persediaan yang dimiliki perusahaan. Apabila nilai perhitungan di bawah satu (1), maka terdapat persediaan yang belum terjual yang nantinya dapat menimbulkan biaya tambahan jika terjadi penumpukan.

d. Rasio Profitabilitas

Rasio ini merupakan rasio untuk menilai kemampuan perusahaan dalam menghasilkan keuntungan. Investor mempertimbangkan profitabilitas lebih penting daripada likuiditas (Bolek \& Wolski, 2012). Rasio ini memberikan ukuran tingkat efektifitas manajemen suatu perusahaan untuk menghasilkan laba melalui semua kemampuannya, dan segala sumber yang ada seperti penjualan, kas, ekuitas, jumlah cabang, dan sebagainya (Harahap, 2009).

1) Net Profit Margin

Rasio ini digunakan untuk mengukur persentase laba bersih yang diperoleh suatu perusahaan dari total penjualan bersihnya.

Rumus:

Net Profit Margin $=\frac{\text { Laba Bersih }}{\text { Penjualan Bersih }} \times 100 \%$

Semakin tinggi hasil perhitungan menunjukkan kondisi perusahaan yang baik sebab menandakan harga penjualan yang ditetapkan mampu untuk menekan beban usaha.

2) Return On Asset (ROA)

Rasio ini menunjukkan persentase return atas jumlah aktiva yang digunakan oleh perusahaan pada proses bisnisnya.

Rumus:

$$
\text { Return on Asset }=\frac{\text { Laba Bersih }}{\text { Total Aktiva }}
$$

Semakin tinggi hasil perhitungan menunjukkan tingkat efektivitas pemanfaatan aset yang semakin baik dalam menghasilkan laba. Perusahaan dikatakan telah menggunakan asetnya secara optimal sehingga mendorong peningkatan laba dari penjualan.

3) Return On Equity (ROE)

Rasio ini digunakan untuk mengetahui rentabilitas dari modal perusahaan. Rasio ini menjadi indikator penting bagi investor terkait pengembalian laba yang mereka bisa dapatkan atas setiap keuntungan bersih yang dihasilkan oleh perusahaan.

Rumus:

$$
\text { Return on Equity }=\frac{\text { Laba Bersih }}{\text { Total Ekuitas }}
$$

Halaman 20 
ANALISIS KINERJA KEUANGAN PERUM BULOG SELAMA PENUGASAN PUBLIC SERVICE OBLIGATION TAHUN 2015 - 2018

I Putu Restu Krisnawan ${ }^{1}$ dan Ambang Aries Yudanto ${ }^{2}$

Semakin tinggi hasil perhitungan maka perusahaan dikatakan semakin baik dalam mengelola modal dan ekuitas yang diterimanya untuk menjalankan peroses bisnis. Sebaliknya bila hasil perhitungan cenderung mendekati nol, perusahaan dikatakan kurang optimal dalam mengelola ekuitas yang dimiliki untuk menghasilkan laba bersih yang tinggi.

\section{METODE PENELITIAN}

\section{Metode Pengumpulan Data}

Metode pengumpulan data yang digunakan adalah metode kepustakaan dan penelitian lapangan.

a. Metode Kepustakaan

Studi kepustakaan merupakan metode penelitian dengan mencari sumber informasi melalui berbagai media untuk mendapatkan dasar teori (Arikunto, 2006). Metode ini dilakukan dengan mengumpulkan data dari hasil panduan dan menelaah beberapa buku, jurnal ilmiah, peraturan, dan sumber tertulis lainnya, tercetak maupun elektronik, yang memiliki hubungan dengan topik yang diangkat.

Studi kepustakaan yang digunakan berupa peraturan perundang-undangan yang memandatkan penugasan kepada Perum BULOG yang nantinya akan dianalisis terkait dampak peraturan tersebut terhadap kegiatan operasional dan kinerja keuangan perusahaan. Penulis juga menganalisis laporan keuangan dan laporan tahunan dari Perum BULOG untuk mendukung analisis.

b. Metode Penelitian Lapangan

Penulis melakukan penelitian lapangan melalui metode wawancara. Menurut Nazir (1999), wawancara adalah proses memperoleh keterangan untuk tujuan penelitian dengan tanya jawab sembari bertatap muka antara pewawancara dan informan. Metode ini dilakukan dengan melakukan tanya jawab dengan narasumber dari internal Perum BULOG untuk mengonfirmasi keakuratan data sekunder yang didapatkan serta mencari informasi lebih dalam terkait strategi-strategi perusahaan.

\section{Metode Analisis Data}

Penulis menggunakan metode analisis deskriptif dengan metode kombinasi. Penelitian deskriptif adalah penelitian yang dilakukan untuk mengetahui keberadaan variabel mandiri, baik hanya pada satu variabel atau lebih tanpa membuat perbandingan atau menghubungkan dengan variabel lainnya (Sugiyono, 2015). Pendekatan deskriptif digunakan untuk mengidentifikasi dan menjelaskan mengenai pemberian PSO terhadap kinerja keuangan Perum BULOG. Penggunaan metode ini diselaraskan dengan variabel penulisan yang sedang dibahas dengan hasil analisis berupa angka-angka yang memiliki makna dan hasil wawancara terhadap pihak Perum BULOG. Sebagaimana dikemukakan oleh Sugiyono (2013:263) bahwa metode penelitian kombinasi akan berguna bila metode kuantitatif dan metode kualitatif secara sendiri-sendiri tidak cukup akurat digunakan untuk memahami permasalahan penelitian, atau dengan menggunakan metode kuantitatif dan kualitatif secara kombinasi akan dapat memperoleh pemahaman paling baik.

\section{ANALISIS DAN PEMBAHASAN}

Tinjauan Kinerja Keuangan Per Akun Krusial

Kondisi keuangan dari Perum BULOG dari tahun 2015 sampai dengan tahun 2018 dapat diamati pada Tabel 1.

Tabel 1 Ikhtisar Keuangan Perum BULOG Tahun 2015-2018

\begin{tabular}{|l|c|c|c|c|c|}
\hline PSO $\rightarrow$ & & Inpres No. 5 Tahun 2015 & Perpres No. 48 Tahun 2016 & Perpres No. 20 Tahun 2017 & 2017 \\
\hline AKUN $\downarrow$ & 2014 & 2015 & 2016 & 2018 \\
\hline Total Aset & Rp20,465,725,129,222 & Rp29,831,584,489,092 & Rp34,586,040,771,064 & Rp29,357,050,119,145 & Rp43,442,902,900,112 \\
\hline Total Liabilitas & Rp16,706,351,701,503 & Rp22,142,745,777,901 & Rp23,604,088,997,522 & Rp17,715,784,116,641 & Rp32,637,136,616,800 \\
\hline Ekuitas & Rp3,759,373,427,719 & Rp7,688,838,711,191 & Rp10,981,951,773,206 & Rp11,641,266,002,504 & Rp10,805,766,283,312 \\
\hline Penjualan & Rp26,562,712,336,051 & Rp32,297,936,386,252 & Rp34,760,713,068,881 & Rp33,010,371,318,826 & Rp28,436,609,609,015 \\
\hline Laba (Rugi) Neto & $\mathbf{R p 4 5 8 , 9 0 8 , 5 7 0 , 8 0 0 )}$ & Rp1,215,604,668,725 & Rp636,435,788,109 & Rp830,980,493,550 & $\mathbf{( R p 9 6 1 , 7 8 5 , 8 9 3 , 3 8 7 )}$ \\
\hline Laba (Rugi) Komprehensif & $\mathbf{( R p 4 5 8 , 9 0 8 , 5 7 0 , 8 0 0 )}$ & Rp931,252,007,099 & Rp644,315,846,084 & Rp659,634,229,298 & $\mathbf{( R p 8 3 5 , 4 9 9 , 7 1 9 , 1 9 2 )}$ \\
\hline
\end{tabular}


ANALISIS KINERJA KEUANGAN PERUM BULOG SELAMA PENUGASAN PUBLIC SERVICE OBLIGATION TAHUN 2015 $-2018$

I Putu Restu Krisnawan ${ }^{1}$ dan Ambang Aries Yudanto ${ }^{2}$

\section{a. Penjualan}

Kinerja Perum BULOG pada periode tahun 2015-2018 cenderung menunjukkan penurunan pada penjualannya. Penjualan sebagai salah satu tolok ukur untuk mengamati performa perusahaan hanya mengalami peningkatan pada tahun 2016 dan menurun pada tahun 2017 hingga 2018. Peningkatan pada tahun 2016 pun tidak terlalu signifikan, hanya 7,63\% menjadi Rp34 triliun dari Rp32 triliun pada tahun 2015.

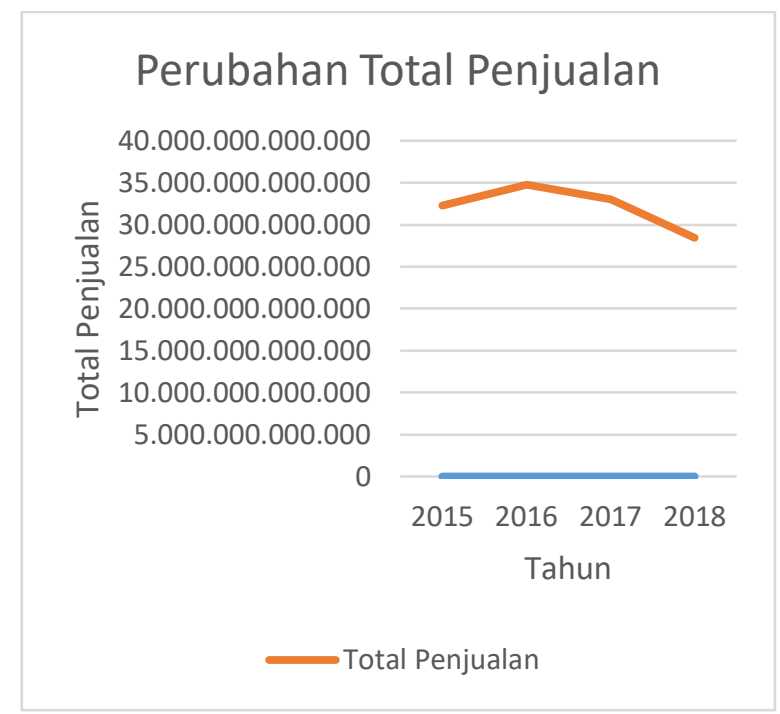

\section{Gambar 2 Grafik Perubahan Total Penjualan Sumber: Data diolah oleh Penulis}

Peningkatan pada tahun 2016 tersebut terjadi karena terdapat peningkatan pendapatan jasa angkutan anak perusahaan, yakni PT JPLB dan UB Jasastama, ke pihak eksternal serta peningkatan penjualan dari beberapa komoditi komersial, seperti gula, daging, dan jagung. Namun, pada tahun 2017 dan 2018 penjualan mengalami penurunan berturut-turut sebesar 5,41\% dan 13,86\%. Penurunan pada tahun 2017 disebabkan oleh penurunan pendapatan PSO. Pada tahun 2018, penurunan juga terjadi pada segmen PSO namun segmen usaha komersial mengalami peningkatan $\mathrm{Rp} 2,34$ triliun yang berasal dari penjualan gula pasir dan daging. Pergerakan grafik total penjualan sangat menarik untuk diamati mengingat pergerakan grafik ini sangat dipengaruhi oleh setiap perubahan PSO maupun kebijakan yang dikeluarkan oleh pemerintah. Penjualan mengalami peningkatan saat Perpres No. 48 Tahun 2016 dikeluarkan. Perpres tersebut mengamanatkan Perum BULOG untuk melaksanakan pendistribusian, pengembangan industri, hingga pengembangan pergudangan yang berdampak pada peningkatan kinerja dari salah satu anak perusahaannya pada bidang jasa angkutan.

Namun, adanya PSO tersebut tidak serta merta memberikan peningkatan performa penjualan yang berkelanjutan pada Perum BULOG. Performa penjualan perusahaan juga sangat dipengaruhi oleh dinamika regulasi yang dikeluarkan oleh pemerintah. Penurunan penjualan yang terjadi selepas tahun 2016 mayoritas disebabkan oleh adanya perubahan regulasi tersebut. Melalui penuturan Divisi Keuangan Perum BULOG, perubahan pola Raskin disubsidi yang diganti ke pola Bantuan Pangan Non Tunai (BPNT) menyebabkan BULOG kehilangan $70 \%$ saluran distribusi terbesar berasnya. Hal tersebut dikarenakan penyaluran beras dalam rangka bantuan sosial menjadi salah satu unsur sumber penyaluran beras terbesar dalam operasional Perum BULOG.

Program Raskin sempat berubah nama menjadi Rastra pada tahun 2015, dan pada tahun 2017 sebagian penerima rastra dialihkan ke BPNT. Berdasarkan data dari Perum BULOG, penyaluran beras Rastra mengalami penurunan pada masa peralihan tersebut menjadi 1,29 juta ton dari 2,79 juta pada tahun sebelumnya. Pada program Rastra, program dirancang berupa subsidi pangan yang diberikan kepada masyarakat ekonomi lemah dalam bentuk beras yang langsung disalurkan oleh Perum BULOG. Sedangkan untuk BPNT, pemerintah melalui Kemensos sebagai koordinator akan memberikan uang tunai kepada keluarga penerima manfaat (KPM) untuk membeli kebutuhan pangan melalui jaringan resmi yang telah disiapkan. Oleh karenanya, Perum BULOG bersaing dengan swasta dalam hal memasok beras untuk program pengadaan bantuan sosial tersebut. Hal itu berimplikasi pada penurunan penjualan dari segmen PSO pada tahun analisis. Implikasi dari hal tersebut adalah BULOG harus mengoptimalkan segmen komersial untuk membantu meningkatkan penjualan. Hal tersebut menunjukkan adanya PSO belum tentu dapat meningkatkan performa perusahaan karena terdapat regulasi-regulasi dan ketentuan pemerintah yang mampu merubah proses bisnis perusahaan.

\section{a. Aset}

Aset Perum BULOG menunjukkan trend peningkatan pada tahun analisis. Walaupun sempat mengalami penurunan pada tahun 2017, total aset kembali menunjukkan peningkatan yang signifikan pada tahun 2018. 
ANALISIS KINERJA KEUANGAN PERUM BULOG SELAMA PENUGASAN PUBLIC SERVICE OBLIGATION TAHUN 2015 $-2018$

I Putu Restu Krisnawan ${ }^{1}$ dan Ambang Aries Yudanto ${ }^{2}$

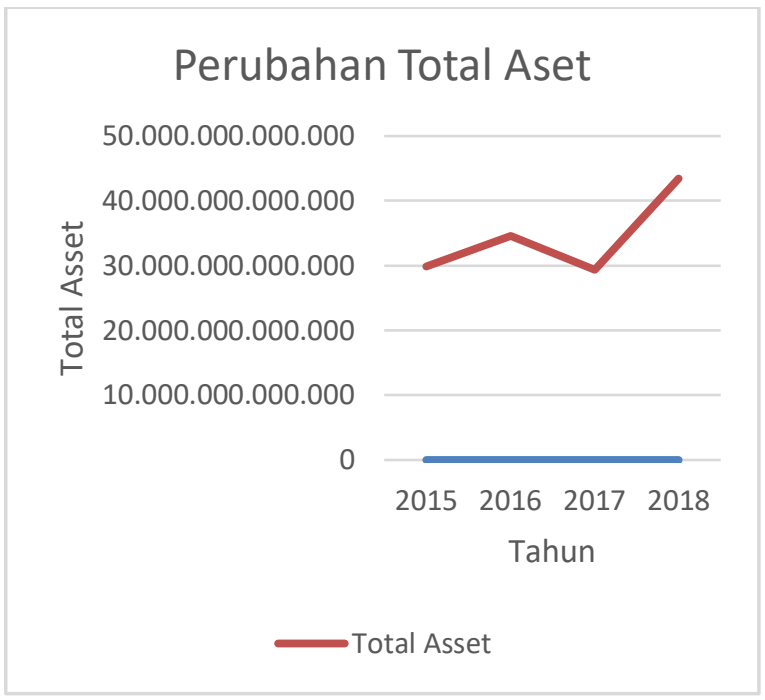

Gambar 3 Pergerakan Perubahan Total Aset Sumber: Data diolah oleh Penulis

Berdasarkan pergerakan grafik tersebut, penurunan total aset pada tahun 2017 terjadi sebesar 15,12\% menjadi Rp29,36 triliun dibandingkan Rp34,59 triliun pada tahun 2016. Penurunan terjadi pada aset lancar maupun aset tidak lancar. Aset tidak lancar perusahaan turun sebesar 18,14\% dari tahun 2016. Penurunan tersebut terjadi karena berkurangnya aset lain-lain sebesar 81,96\% dari Rp2,67 triliun menjadi Rp480,64 miliar. Aset tidak lancar juga mengalami penurunan yang signifikan, terlebih penurunan pada persediaan sebesar 29,34\% karena penurunan persediaan barang dagangan PSO dan komersial. Oleh karenanya, total aset mengalami penurunan setelah sempat meningkat pada tahun 2016.

Pada tahun 2018, total aset mengalami peningkatan sebesar 47,98\% menjadi Rp43,4 triliun dari tahun 2017. Pada grafik tersebut, aset mengalami peningkatan yang cukup signifikan pada tahun 2018, bahkan peningkatannya lebih tinggi dari tahun 2016. Peningkatan persediaan kembali terjadi yang mendorong peningkatan aset lancar sebesar 49,11\%. Peningkatan persediaan terjadi karena komoditas gabah/beras PSO yang didapat dari impor beras tahun 2018. Selain itu, aset tetap perusahaan juga mengalami peningkatan sebesar 43,33\% yang didominasi oleh peningkatan bangunan dan inventaris untuk mendorong proses bisnis dan pelaksanaan PSO yang diberikan.

Kondisi dari aset perusahaan yang paling terdampak dari adanya PSO adalah aset tidak lancar berupa persediaan. Adanya penugasan berupa impor dan kewajiban melakukan penyerapan beras dalam negeri pada kondisi tertentu menyebabkan kenaikan persediaan perusahaan. Hal tersebut dapat diamati pada perkembangan persediaan perusahan yang menunjukkan trend peningkatan, bahkan signifikan pada tahun 2018. Namun, peningkatan persediaan tersebut tidak diimbangi dengan adanya kenaikan pada total penjualan. Hal ini kembali disebabkan oleh adanya regulasi yang mempengaruhi proses penyaluran beras pada segmen PSO. Pergerakan persediaan ini akan diamati lebih dalam pada bagian rasio yang menjelaskan aktivitas persediaan.

b. Liabilitas dan Ekuitas

Pergerakan total liabilitas dari Perum BULOG selama tahun analisis dapat diamati pada Gambar 4.

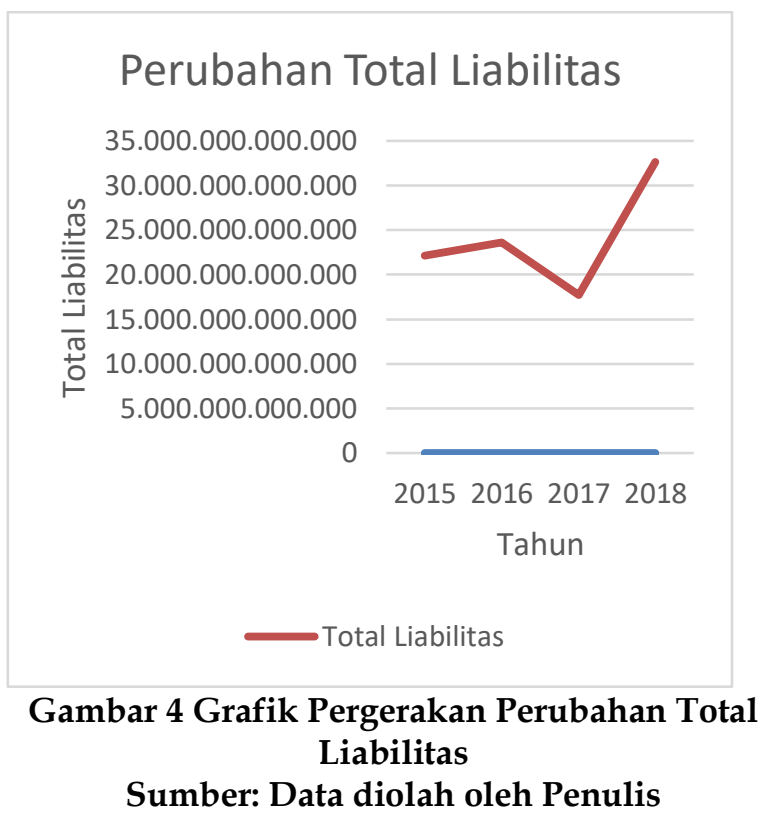

Pada tahun 2015-2018 liabilitas Perum BULOG menunjukkan volatilitas pada pergerakannya. Liabilitas perusahaan naik pada tahun 2016, turun pada tahun 2017, dan naik signifikan pada tahun 2018. Pada tahun 2016, liabilitas meningkat sebesar $6,43 \%$ menjadi Rp23,57 triliun sehingga terjadi kenaikan pada grafik tahun 2016. Liabilitas jangka pendek meningkat sebesar 5,66\% yang terjadi karena adanya peningkatan utang bank untuk pengadaan komoditi PSO dan komersial. Liabilitas jangka pendek perlu menjadi perhatian terkait dengan PSO yang diemban oleh Perum BULOG. Berdasarkan Perpres No. 48 Tahun 2016, sumber pendanaan yang dapat digunakan untuk melaksanakan penugasan dapat berupa dana perusahaan, ataupun sumber pendanaan dari lembaga keuangan dalam negeri. Sejauh ini, sumber dana BULOG semua menggunakan modal kerja milik BULOG sendiri dan dibantu dengan pinjaman kredit perbankan. Pada akhir tahun, akan terdapat audit terkait beberapa pos yang dikeluarkan dan akan diberikan penggantian oleh pemerintah berdasarkan hasil audit. Namun, berdasarkan hasil wawancara, Perum BULOG menyatakan bahwa proses penggantian ini memakan waktu yang lama sehingga pembayaran kredit perbankan terkadang harus ditanggung 
oleh keuangan Perum BULOG sendiri yang berimplikasi pada terbebaninya pos utang bank jangka pendek.

Terkait dengan penggunaan kredit perbankan, sebelum tahun 2016, BULOG masih mendapat fasilitas jaminan kredit perbankan dari pemerintah. Namun, jaminan tersebut mulai dihentikan sejak tahun 2016. Hal tersebut dikarenakan adanya permasalahan terkait regulasi yang ada. Pada Perpres No. 48 Tahun 2016 terdapat klausul terkait sumber pendanaan, namun regulasi untuk mendukung pelaksanaan Perpres tersebut belum ada. Kementerian Keuangan belum menerbitkan dasar untuk memberikan fasilitas tersebut sebagai payung hukum.

Berubahnya program Rastra juga berimplikasi pada kondisi liabilitas perusahaan. Hilangnya rantai penyaluran distribusi beras menyebabkan Perum BULOG harus mengoptimalkan segmen bisnis komersial untuk meningkatkan penjualan sekaligus tetap mengoptimalkan pelaksanaan PSO. Pengembangan pada segmen komersial menyebabkan kenaikan utang bank jangka pendek pada tahun 2018 yang berimplikasi pada naiknya total liabilitas. Utang jangka pendek pada tahun 2018 meningkat sebesar 121,37\% dari tahun sebelumnya. Utang-utang tersebut digunakan untuk kedua segmen usaha. Pada segmen PSO, utang tersebut digunakan sebagai pinjaman modal kerja dan fasilitas jaminan penangguhan impor dengan agunan fidusia atas persediaan gabah/beras. Sedangkan untuk segmen komersial digunakan sebagai pinjaman modal kerja untuk barang-barang yang diperdagangkan.

Pada tahun analisis, saat beberapa PSO diberikan melalui beberapa regulasi, pemerintah juga memberikan beberapa insentif pada Perum BULOG. Beberapa diantaranya berupa PMN pada tahun 2015 melalui PP No. 49 Tahun 2015 sebesar Rp3 triliun dan tahun 2016 melalui PP No. 70 Tahun 2016 sebesar Rp2 triliun. PMN tersebut difokuskan untuk perbaikan struktur permodalan dan peningkatan pada kapasitas usaha untuk mendorong kinerja dan pelaksanaan penugasan. Pembangunan sarana produksi dan tempat penyimpanan mulai dilakukan untuk meningkatkan kemampuan pengelolaan gabah/beras dan komoditas lain. Selain itu, perbaikan infrastruktur juga dilakukan, terutama untuk infrastruktur pascapanen (BULOG, 2017). Pemberian PMN tersebut mendorong peningkatan ekuitas yang dimiliki perusahaan.

Selain pemberian PMN, pemerintah juga memberikan kelonggaran dalam hal fleksibilitas harga dari PSO yang tertuang dalam Inpres No. 5 Tahun 2015. Divisi Keuangan menuturkan bahwa jika terkait harga, sebenarnya jika dibandingkan dengan harga pasar telah terjadi ketidaksesuaian. Terlebih HPP di tingkat pasar mengalami kenaikan yang signifikan pada tahun 2015 hingga 2018. Setiap tahun rata-rata kenaikannya mencapai 2,6\% dari HPP pada tingkat pasar. Hal tersebut menyebabkan pemerintah memberikan fleksibilitas harga pada tahun 2017 dan 2018 sebesar 10\% dari HPP pada Inpres No. 5 Tahun 2015. Hal tersebut ditujukan untuk menyeimbangkan HPP pada regulasi dengan harga pasar. Selain itu, BULOG juga sempat mendapatkan fasilitas bebas bea untuk impor beras, namun untuk saat ini sudah sesuai dengan tarif yang diterapkan oleh Direktorat Kepabeanan dan Cukai. BULOG tidak mendapat fasilitas bebas tarif ataupun keringanan untuk penugasan pengadaan melalui impor.

\section{Analisis Kinerja Keuangan Melalui Rasio Keuangan \\ Untuk mengamati pergerakan kinerja} keuangan Perum BULOG, berikut adalah grafik perubahan rasio-rasio keuangan Perum BULOG saat diberikan PSO pada tahun 2015 sampai dengan tahun 2018.

1. Rasio Likuiditas

\section{a. Current ratio}

Data pergerakan current ratio Perum BULOG selama periode tahun analisis digambarkan pada grafik berikut ini.

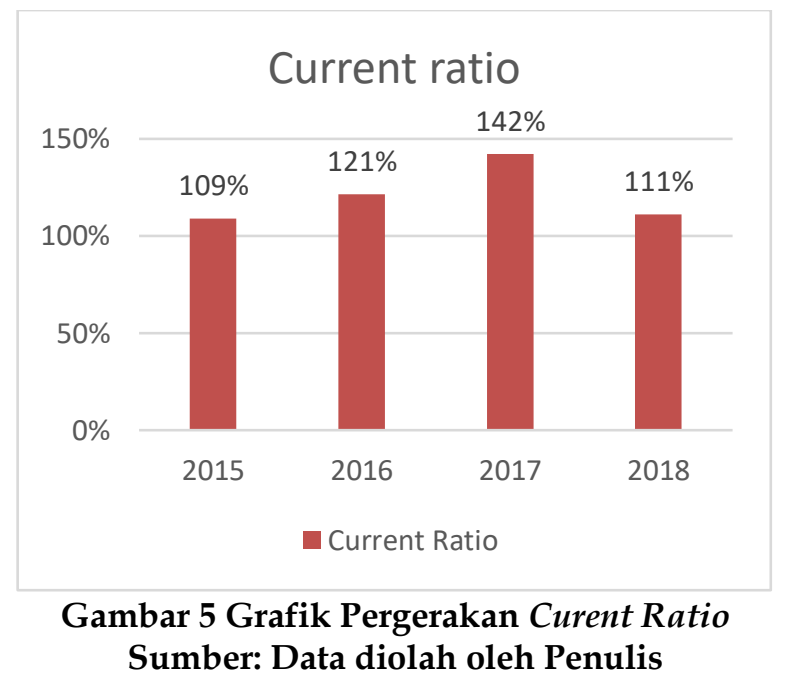

Perkembangan current ratio dari Perum BULOG mengalami tendensi peningkatan selama tiga tahun pertama analisis, dan menurun pada tahun 2018. Pada tahun 2016, current ratio BULOG mengalami peningkatan sebesar $11 \%$ atau naik $12 \%$ dari $109 \%$ menjadi $121 \%$. Peningkatan tersebut disebabkan adanya kenaikan pada aset lancar lainnya sebesar 113,104\% menjadi Rp333,40 miliar pada tahun 2016 dibandingkan Rp294,51 juta pada tahun 2015. Kenaikan aset lancar lainnya disebabkan meningkatnya selisih harga penyaluran raskin pada tahun 2016 dari tahun 2015. Persediaan pada tahun tersebut juga mengalami peningkatan sebesar $81,32 \%$ karena naiknya persediaan barang dagangan PSO berupa 
beras dan gabah serta komersial berupa beras dan gabah komersial. Selain itu, kas dan setara kas juga meningkat sebesar 37,33\% menjadi Rp6,69 triliun dibandingkan Rp4,87 triliun pada tahun 2015. Walaupun liabilitas mengalami peningkatan pada tahun 2016, meningkatnya aktiva lancar berupa persediaan, kas dan setara kas, serta aset lancar lainnya mampu meningkatkan likuiditas perusahaan.

Pada tahun 2017, current ratio BULOG kembali menunjukkan peningkatan walaupun aset lancar perusahaan mengalami penurunan persediaan sebesar 29,34\% baik pada segmen PSO maupun komersial. Kenaikan current ratio pada tahun ini didorong oleh penurunan liabilitas jangka pendek perusahaan sebesar 26,8\% menjadi Rp16,62 triliun dari Rp22,71 triliun pada tahun 2016. Penurunan liabilitas jangka pendek ini didorong oleh penurunan utang bank untuk pengadaan komoditi PSO sebesar 48,80\% dan komoditi komersial sebesar $17,89 \%$.

Namun, current ratio Perum BULOG kembali menunjukkan penurunan pada tahun 2018 sebesar $21,83 \%$ menjadi $111 \%$ dari $142 \%$ pada tahun 2017 . Walaupun aset lancar mengalami peningkatan $49,11 \%$, namun liabilitas jangka pendek pada tahun 2018 mengalami kenaikan yang signifikan sebesar $90,54 \%$. Hal ini didorong oleh peningkatan utang bank jangka pendek sebesar 121,37\% menjadi Rp29,31 triliun. Peningkatan tersebut disebabkan oleh perusahaan yang ingin meningkatkan modal kerja melalui pinjaman untuk mengembangkan kedua segmen usaha, seperti fasilitas jaminan penangguhan impor untuk PSO dan modal kerja untuk barang dagangan untuk komersial.

Melirik perkembangan current ratio dari Perum BULOG, maka dapat dikatakan jika kondisi likuiditas perusahaan berada dalam kondisi yang baik mengingat hasil perhitungan menunjukkan nilai di atas $100 \%$. Namun, ada beberapa hal yang perlu diperhatikan, seperti kontrol persediaan pada aset lancar serta pengunaan utang bank jangka pendek. BULOG harus melakukan pengelolaan yang optimal terhadap persediaannya mengingat komposisi persediaan sangat signifikan terhadap aset lancar perusahaan. Selain itu, BULOG juga perlu melakukan evaluasi terhadap setiap utang bank yang dilakukan untuk setiap pelaksanaan PSO, baik itu untuk modal kerja maupun jaminan untuk penangguhan impor agar tidak terlalu membebani likuiditas perusahaan. Pengembangan usaha segmen komersial yang menggunakan utang bank jangka pendek juga perlu dioptimalkan agar jumlah utang bank yang tinggi tersebut dapat berdaya guna secara optimal.

b. Quick ratio
Data pergerakan quick ratio dari Perum BULOG selama periode tahun analisis dapat diamati pada grafik berikut ini.

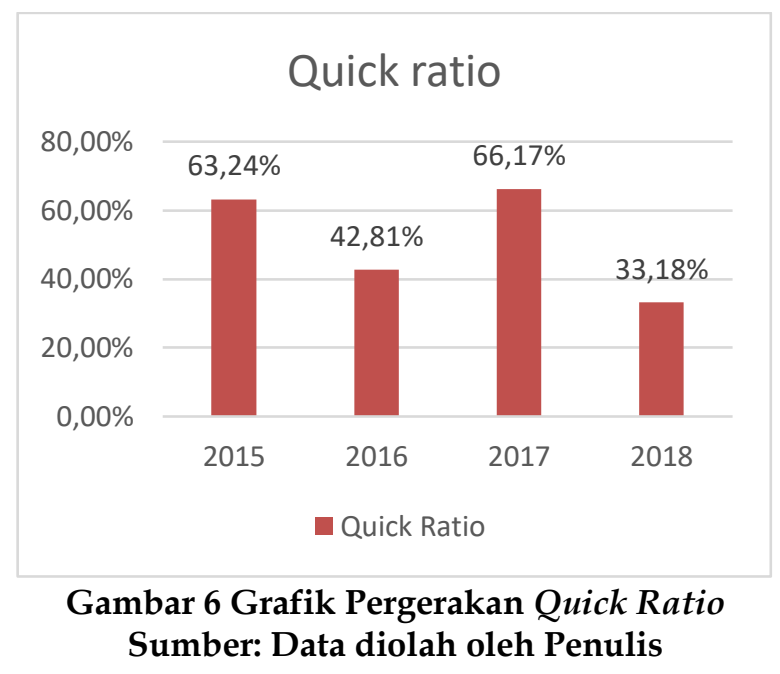

Perkembangan quick ratio dari Perum BULOG selama tahun analisis cenderung sangat fluktuatif dan sangat dipengaruhi oleh pergerakan jumlah persediaan. Hal tersebut dapat dilihat pada tahun 2016 saat rasio mengalami penurunan sebesar $32,31 \%$, persediaan mengalami peningkatan signifikan sebesar $82,64 \%$ walaupun kas dan setara kas juga mengalami peningkatan sebesar 37,82\%. Hal yang sama juga dapat diamati pada tahun 2017 saat persediaan mengalami penurunan sebesar $29,35 \%$, quick ratio perusahaan meningkat sebesar 54,57\% menjadi 66,17\%. Pada tahun 2018, persediaan kembali mengalami kenaikan signifikan sebesar 95,81\% dan menurunkan quick ratio sebesar $49,86 \%$ dari $66,17 \%$ menjadi $33,18 \%$.

Pengaruh dan pengurangan persediaan dari aset lancar untuk mengetahui likuiditas perusahaan secara lebih mendalam memiliki dampak yang signifikan terhadap jumlah aset lancar. Hal tersebut mengindikasikan bahwa aset lancar Perum BULOG didominasi oleh persediaan. Hal tersebut berimplikasi pada volatilitas dari perhitungan quick ratio perusahaan. Walaupun kas dan setara kas perusahaan memainkan peran yang penting dalam perhitungan ini, namun perkembangannya tidak terlalu signifikan dan jumlahnya jauh di bawah persediaan. Oleh karenanya, kondisi persediaan perusahaan berimplikasi besar pada penilaian terhadap likuiditas Perum BULOG. Hasil dari perhitungan quick ratio Perum BULOG kembali menekankan bahwa pengelolaan terhadap persediaan sangat krusial terhadap kondisi keuangan perusahaan. Selain itu, optimalisasi pengelolaan piutang juga dapat dilakukan dan perlu evaluasi kembali oleh Perum BULOG agar dapat mendorong kondisi likuiditas perusahaan.

c. Cash ratio 
ANALISIS KINERJA KEUANGAN PERUM BULOG SELAMA PENUGASAN PUBLIC SERVICE OBLIGATION TAHUN 2015 $-2018$

I Putu Restu Krisnawan ${ }^{1}$ dan Ambang Aries Yudanto ${ }^{2}$

Data pergerakan cash ratio dari Perum BULOG selama periode tahun analisis dapat diamati pada grafik berikut ini.

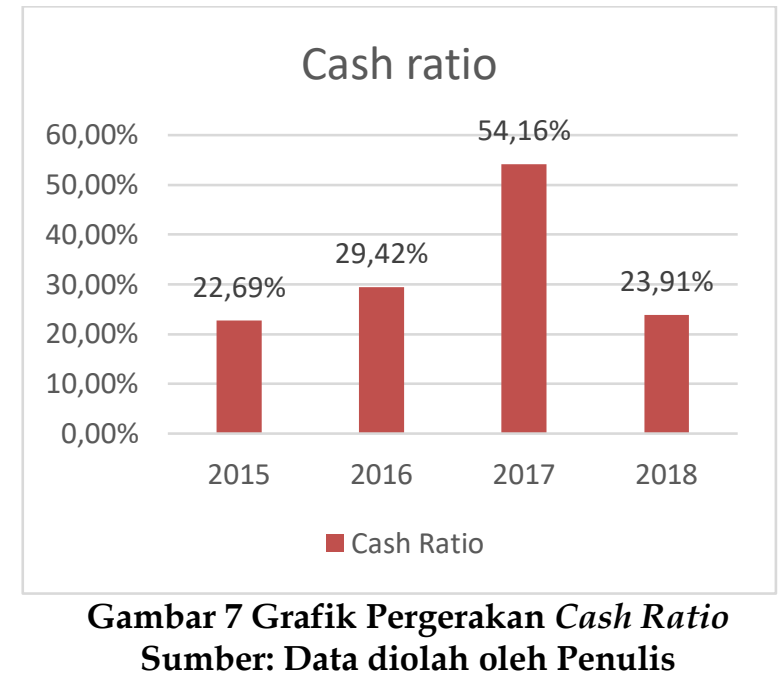

Perkembangan cash ratio dari Perum BULOG pada tahun analisis cenderung mengalami kenaikan pada tiga tahun pertama tahun analisis dan turun pada tahun 2018. Pada tahun 2016, cash ratio BULOG meningkat sebesar $29,66 \%$ dari $22,69 \%$ menjadi $29,42 \%$. Hal ini didorong oleh peningkatan kas dan setara kas sebesar $37,28 \%$ menjadi Rp6,68 triliun dari Rp4,868 triliun pada tahun 2015. Peningkatan ini disebabkan oleh meningkatnya setara kas berupa penempatan dana di bank. Cash ratio meningkat signifikan sebesar 84,09\% pada tahun 2017 menjadi 54,16\%. Hal tersebut disebabkan oleh kenaikan kas sebesar 34,75\% menjadi Rp9,006 triliun dari Rp6,683 triliun pada tahun 2016 yang didorong oleh kenaikan setara kas berupa penempatan dana di bank. Selain itu, pada tahun 2017, liabilitas perusahaan juga mengalami penurunan yang mendorong kenaikan cash ratio perusahaan.

Namun, pada tahun 2018, cash ratio BULOG mengalami penurunan yang signifikan sebesar $55,85 \%$ menjadi $23,91 \%$ dari $54,16 \%$. Penurunan tersebut didorong oleh adanya peningkatan signifikan pada liabilitas jangka pendek sebesar 90,54\% yang digunakan untuk modal kerja dan fasilitas penangguhan impor PSO dan komersial. Selain itu, kas dan setara kas juga mengalami penurunan sebesar $15,89 \%$ karena turunnya dana bank PSO sebesar 24,22\% menjadi Rp2,23 triliun dari Rp4,26 triliun pada tahun 2017.

Pergerakan dari cash ratio perusahaan menunjukkan bahwa Perum BULOG harus mampu meningkatkan likuiditas perusahaan melalui peningkatan jumlah kas dan setara kas, selain melakukan pengelolaan terhadap utang jangka pendeknya. Hal tersebut dapat dilakukan dengan mendorong penjualan secara kas, dan mengoptimalkan penyelesaian piutang yang dimiliki. Hal ini juga dalam rangka untuk peningkatan efisiensi perusahaan, dalam rangka mengakomodasi operasioanl perusahaan ketika situasi pasar cenderung lebih likuid (Avramov et al., 2006).

2. Rasio Solvabilitas

a. Debt to Total Equity Ratio

Data pergerakan debt to total equity ratio dari Perum BULOG selama periode analisis dapat diamati pada grafik berikut ini.

\section{Debt to Total Equity Ratio}

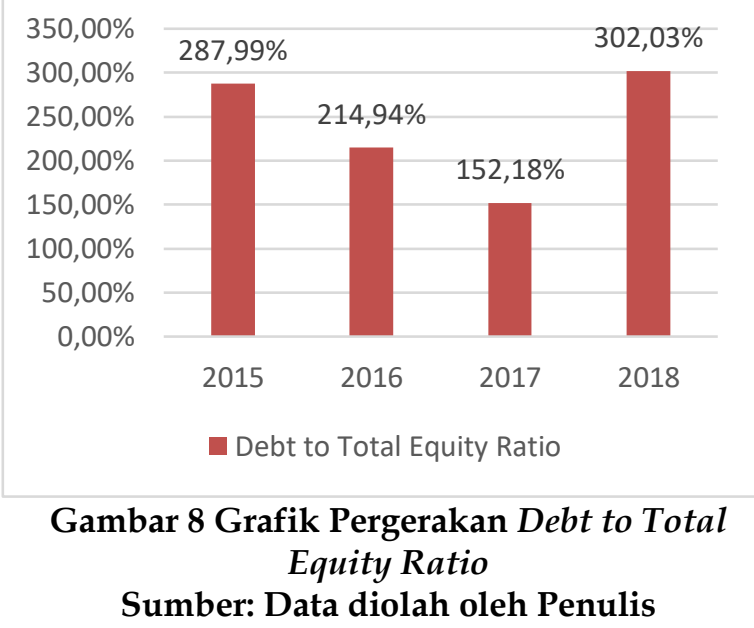

Pergerakan debt to total equity ratio dari Perum BULOG pada tahun analisis menunjukkan peningkatan pada tahun 2016 hingga 2017 dan kondisinya kembali menurun pada tahun 2018. Pada tahun 2016, debt to total equity ratio menurun sebesar $25,37 \%$ menjadi $214,94 \%$ dari $287,99 \%$ pada tahun 2015. Kondisi tersebut menunjukkan kondisi perusahaan yang makin membaik. Perusahaan tersebut didorong oleh peningkatan jumlah ekuitas perusahaan sebesar $42,83 \%$ yang disebabkan oleh bertambahnya total ekuitas yang dapat diatribusikan kepada pemilik entitas induk.

Pada tahun 2017, debt to total equity ratio BULOG kembali mengalami perbaikan dengan menurunnya hasil perhitungan sebesar $29,20 \%$ menjadi 152,18\%. Peningkatan kondisi ini disebabkan oleh penurunan total liabilitas. Selain itu, total ekuitas perusahaan juga meningkat sebesar $6 \%$ yang disebabkan oleh kenaikan laba periode berjalan. Namun pada tahun 2018, rasio ini kembali mengalami kenaikan signifikan sebesar $98,47 \%$ menjadi $302,03 \%$. Hal ini didorong oleh kenaikan liabilitas dan penurunan ekuitas yang disebabkan oleh peningkatan jumlah defisit yaitu sebesar Rp923,23 miliar.

Pergerakan pada debt to total equity ratio dari Perum BULOG menekankan pada aspek ekuitas. Hal tersebut berimplikasi pada kinerja penjualan dan kontrol terhadap beban yang dimiliki oleh 
perusahaan. Hal tersebut dikarenakan adanya laba atau defisit akan mempengaruhi total ekuitas, mengingat bagian modal pemerintah pada ekuitas tidak dapat dipastikan karena dipengaruhi oleh faktor yang kompleks dan jumlah cenderung tetap pada tahun analisis. Performa kinerja dan kontrol terhadap beban perusahaan menjadi salah satu langkah yang ditempuh untuk meningkatkan ekuitas perusahaan. Adanya PSO serta perubahan regulasi yang ada turut berpengaruh signifikan seperti ketika perubahan Rastra menjadi BPNT yang menurunkan penjualan. Oleh karenanya, BULOG harus berusaha untuk memaksimalkan segmen komersial dan unit usaha serta anak perusahaannya untuk mendorong penjualan. Beban dari perusahaan, terutama beban keuangan dari segmen bisnis PSO juga harus ditekan agar tidak menyebabkan defisit pada laporan laba rugi.

b. Debt to Total Asset Ratio

Data pergerakan debt to total asset ratio dari Perum BULOG selama periode tahun analisis dapat diamati pada grafik berikut ini.

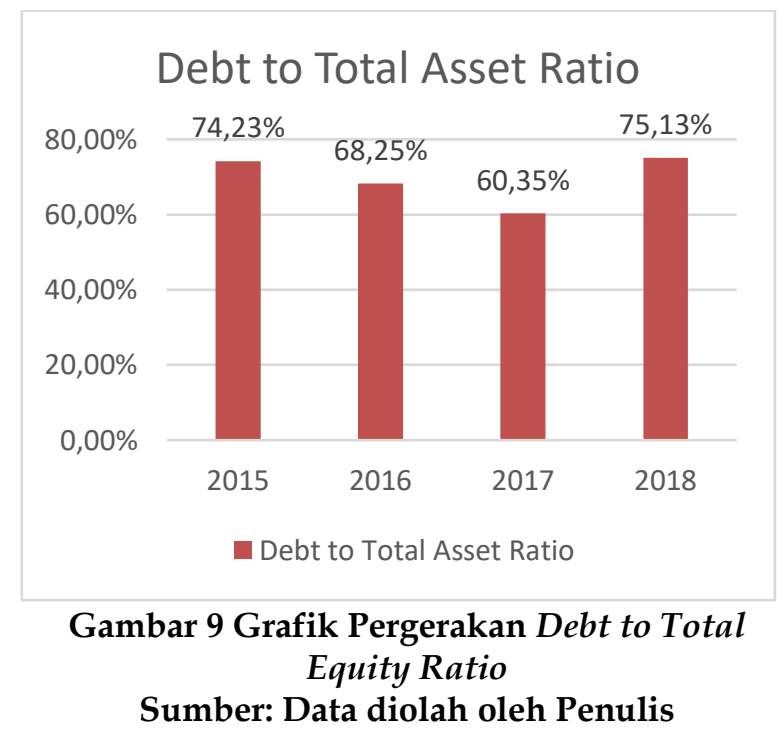

Data debt to total asset ratio dari Perum BULOG cenderung mengalami kenaikan pada tahun 2015 hingga 2017 dan kembali menunjukkan penurunan pada tahun 2018. Kinerja dari rasio ini sejalan dengan pergerakan jumlah total aset perusahaan kecuali pada tahun 2017 di mana total aset mengalami penurunan yang diiringi dengan penurunan signifikan pada liabilitas sehingga menurunkan nilai rasio ini. Peningkatan pada jumlah total aset terjadi pada tahun 2018 namun diiringi dengan liabilitas yang juga meningkat menyebabkan nilai rasio ini naik. Walaupun rasio ini menunjukkan tendensi perbaikan dari tahun ke tahun, Perum BULOG harus memastikan bahwa aset yang dimiliki dapat memberikan manfaat optimal terhadap kinerja perusahaan. Meningkatnya jumlah liabilitas yang digunakan untuk pembelian aset berupa bangunan dan inventaris untuk mendorong pelaksanaan penugasan, seperti yang terjadi pada tahun 2018, harus dimanfaatkan untuk meningkatkan modal kerja guna meningkatkan aspek produktivitas dari aset tersebut.

3. Rasio Aktivitas

a. Total Asset Turnover

Data pergerakan total asset turnover dari Perum BULOG selama periode tahun analisis dapat diamati pada grafik berikut ini.

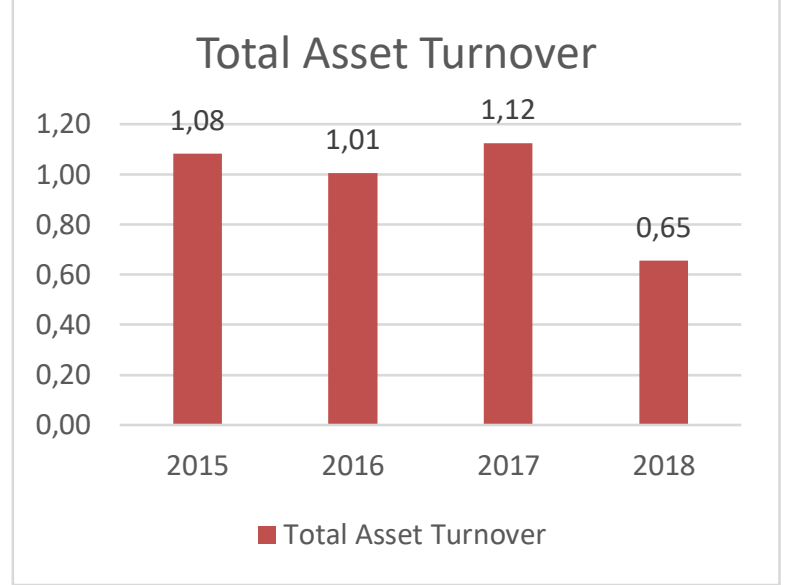

\section{Gambar 10 Grafik Pergerakan Total Asset Turnover \\ Sumber: Data diolah oleh Penulis}

Perputaran total aset dari Perum BULOG mengalami fluktuasi setiap tahunnya. Pada tahun 2015 hingga tahun 2017, rasio ini masih menunjukkan angka di atas 1 (satu) yang berarti perputaran dari total aset telah mampu mendorong peningkatan pada penjualan. Walaupun sempat mengalami penurunan pada tahun 2016 yang disebabkan oleh peningkatan pada total aset, namun tetap diiringi dengan kenaikan pada penjualan yang berarti total aset yang ada telah dioptimalkan penggunaannya. Namun pada tahun 2018 rasio perputaran total aset menurun di bawah satu menjadi 0,65. Hal tersebut dikarenakan terjadi penurunan yang signifikan pada penjualan sebesar $13,86 \%$ menjadi Rp28,436 triliun dari Rp33,01 triliun pada tahun 2017. Hal ini disebabkan oleh hilangnya beberapa rantai penyaluran beras sejak diubahnya program rastra menjadi BPNT. Selain itu, total aset perusahaan juga mengalami peningkatan sebesar $47,98 \%$ yang disebabkan oleh naiknya jumlah persediaan akibat impor dan pembelian aset tetap.

b. Fixed Asset Turnover

Data pergerakan fixed asset turnover dari Perum BULOG selama periode tahun analisis dapat diamati pada grafik berikut ini. 
ANALISIS KINERJA KEUANGAN PERUM BULOG SELAMA PENUGASAN PUBLIC SERVICE OBLIGATION TAHUN 2015 $-2018$

I Putu Restu Krisnawan ${ }^{1}$ dan Ambang Aries Yudanto ${ }^{2}$

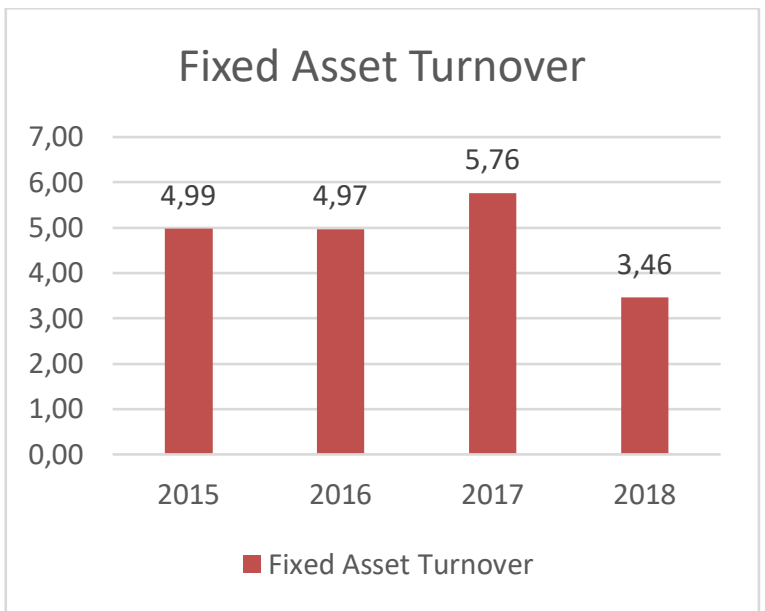

\section{Gambar 11 Grafik Pergerakan Fixed Asset Turnover}

Sumber: Data diolah oleh Penulis

Rasio perputaran dari aset tetap Perum BULOG menunjukkan trend peningkatan dari tahun 2015-2017 walaupun terjadi sedikit penurunan pada tahun 2016 dikarenakan adanya sedikit penambahan pada aset tetap. Pada tahun 2017 rasio ini meningkat dikarenakan penurunan pada aset tetap sebesar 18,09\% menjadi Rp5,732 triliun. Penurunan ini dikarenakan adanya penurunan pada aset lain-lain perusahaan. Namun, pada tahun 2018 rasio ini menurun $39,93 \%$ karena penurunan penjualan yang signifikan dan adanya penambahan aset tetap pembelian gedung.

Pada tahun analisis, saat beberapa PSO dan perubahan PSO diberikan, rasio perputaran aset dari Perum BULOG sangat dipengaruhi oleh kondisi penjualan bersihnya. Aset tetap perusahaan sudah dioptimalkan untuk mendorong pelaksanaan penugasan dan meningkatkan kinerja perusahaan. Namun, terdapat pula faktor-faktor eksternal lain, seperti adanya regulasi tertentu, yang ternyata lebih mempengaruhi pergerakan dari penjualan itu sendiri. Jika disimpulkan, Perum BULOG telah memiliki performa aset tetap yang baik untuk mendorong kinerja perusahaan.

\section{c. Inventory Turnover}

Data pergerakan inventory turnover dari perum BULOG selama periode tahun analisis dapat diamati pada grafik berikut ini.

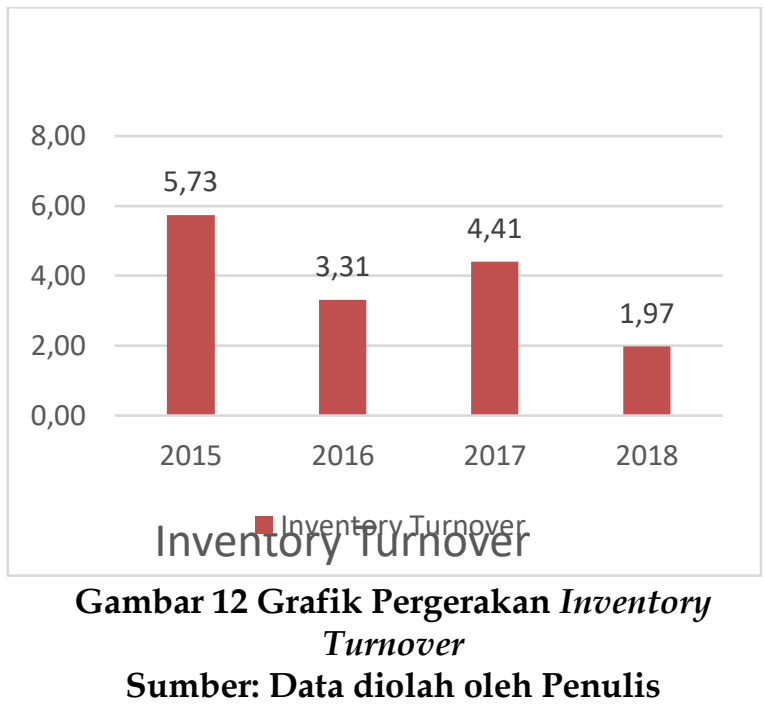

Jika dilihat, pada tahun analisis rasio perputaran persediaan sangat fluktuatif dan menunjukkan trend penurunan. Hal ini sejalan dengan perkembangan persediaan dari Perum BULOG. Pada tahun 2016, persediaan meningkat sebesar 83\% menjadi Rp17,862 triliun dari Rp9,78 triliun pada tahun 2015. Hal ini menyebabkan perputaran persediaan menurun menjadi 3,31 kali. Hal yang sama juga terjadi pada tahun 2018, persediaan menunjukkan kenaikan sebesar $95,81 \%$ menjadi Rp24,71 triliun dari Rp12,62 triliun pada tahun 2017. Rasio perputaran turun menjadi 1,97 kali yang mengindikasikan perusahaan mengalami penjualan yang kecil dan ditunjukkan dengan penurunan sebesar $13,86 \%$ pada tahun 2018.

Pada tahun 2018, Perum BULOG memiliki penumpukan persediaan yang banyak dan tidak diimbangi dengan penjualan yang tinggi. Penjualan justru mengalami penurunan. Hal ini berimplikasi pada menumpuknya persediaan yang dapat meningkatkan beban perusahaan. Adanya penugasan untuk impor beras oleh pemerintah pada tahun 2018 sebesar 1,8 juta ton menyebabkan stok CBP meningkat mencapai 442\% dibandingkan perkiraan pada RKAP 2018. Oleh karenanya, BULOG mencoba menerapkan pengelolaan persediaan dengan melakukan penyebaran stok dari divisi regional/subdivisi regional yang surplus persediaan ke divisi regional/subdivisi regional yang mengalami defisit persediaan. Selain itu, BULOG juga telah melaksanakan penyaluran bansos Rastra dan mengoptimalkan tempat penyimpanan pada gudang agar proses pemindahan dan transfer persediaan tersebut dapat berjalan dengan lancar dan tepat waktu.

Adanya penugasan untuk melakukan impor maupun penyerapan beras menyebabkan kontrol terhadap persediaan menjadi krusial untuk dilakukan. Oleh karenanya, adanya PSO juga menjadi salah satu alasan di balik perputaran persediaan Perum BULOG yang kecil. Untuk 
menyikapi hal tersebut, selain melakukan hal yang telah disebutkan di atas, BULOG juga mencoba untuk memaksimalkan penjualan melalui optimalisasi segmen komersial agar mempercepat perputaran persediaan yang dimiliki.

4. Rasio Profitabilitas

a. Net Profit Margin

Data pergerakan net profit margin dari Perum BULOG sealam periode tahun analisis dapat diamati pada grafik berikut ini.

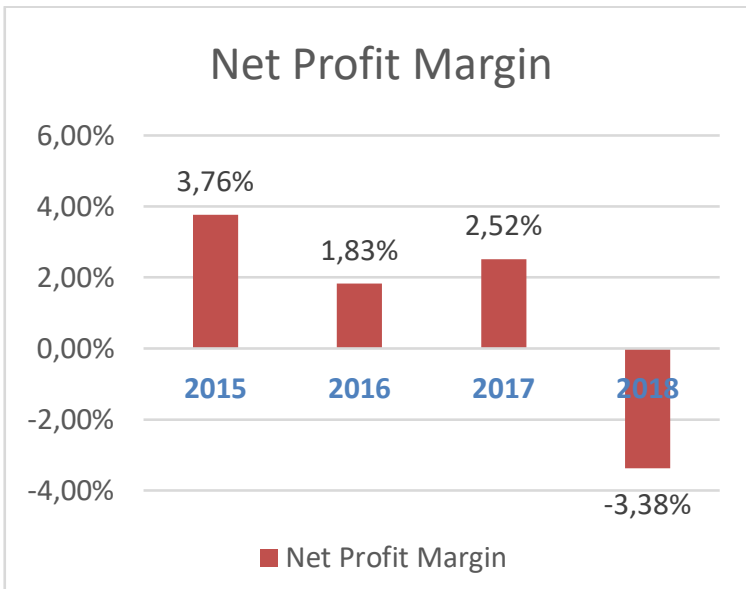

Gambar 13 Grafik Pergerakan Net Profit Margin Sumber: Data diolah oleh Penulis

Pergerakan net profit margin dari Perum BULOG cenderung fluktuatif. Rasio ini menunjukkan bahwa pemberian PSO pada Perum BULOG tidak serta merta akan meningkatkan kinerja keuangan Perum BULOG. Pada tahun 2016, net profit margin mengalami penurunan menjadi 1,83\% dikarenakan penurunan laba bersih setelah pajak sebesar 47,64\% menjadi Rp636,43 miliar dari Rp1,215 triliun pada tahun 2015. Walaupun pada tahun 2016 penjualan mengalami peningkatan, namun beban keuangan perusahaan juga meningkat sebesar $41,14 \%$. Hal tersebut didorong oleh peningkatan biaya bunga sebesar 35,04\% untuk PSO dan komersial. Beban keuangan tersebut didorong oleh pelaksanaan pengadaan beras pada proses PSO yang menggunakan pinjaman perbankan. Beban bunga tersebut akan meningkat saat ada penugasan seperti pelaksanaan impor beras/gabah seperti tahun 2018. Hal ini akan berimplikasi pada naiknya beban keuangan dari Perum BULOG. Terlebih jika penugasan terkait pengadaan/penyerapan beras/gabah tersebut tidak diimbangi dengan aspek penyaluran, penjualan akan mengalami penurunan di saat beban keuangan terus mengalami peningkatan. Selain dari PSO, beban keuangan tersebut juga timbul dari usaha perusahaan untuk meningkatkan penjualan dari segmen komersial. Hal tersebut dapat dilihat pada tahun 2018 saat net profit margin BULOG menunjukkan angka $-3,38 \%$. Pada tahun tersebut, penjualan mengalami penurunan dan beban keuangan mengalami peningkatan sebesar $11,63 \%$. Oleh karenanya, melalui analisis rasio ini dapat dikatakan bahwa Perum BULOG perlu untuk meningkatkan aspek penjualan sekaligus mengontrol beban-beban yang ditanggungnya.

b. Return on Asset (ROA)

Data pergerakan return on asset (ROA) dari Perum BULOG selama periode tahun analisis dapat diamati pada grafik berikut ini.

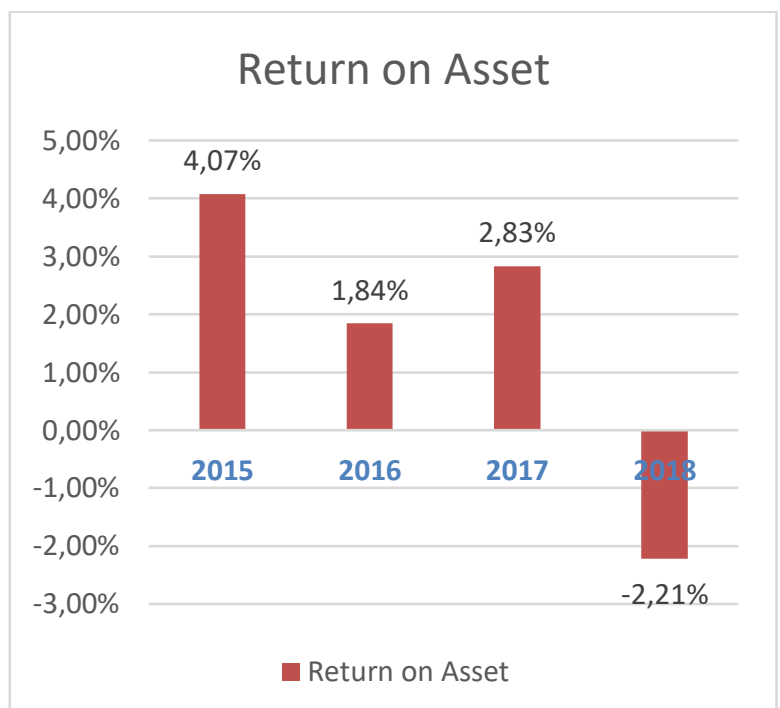

\section{Gambar 14 Grafik Pergerakan Return on Asset Sumber: Data diolah oleh Penulis}

Perhitungan rasio ROA pada Perum BULOG menunjukkan hasil yang fluktuatif sejalan dengan pertumbuhan laba bersih perusahaan. Rasio ini turun pada tahun 2018 menjadi 1,84\% karena penurunan laba bersih dan total aktiva yang meningkat sebesar 15,94\%. Pada tahun 2017, rasio ini meningkat seiring dengan kenaikan laba bersih dan penurunan total aset. Kemudian tahun 2018, ROA Perum BULOG turun sampai $-2,21 \%$ dikarenakan penurunan pada laba bersih sebesar 215,74\% menjadi Rp-961,785 miliar. Selain itu total aset juga meningkat signifikan sebesar 47,98\% yang didominasi oleh kenaikan persediaan pada aset lancar.

Melalui pergerakan rasio ini, total aset perusahaan belum mampu mendorong performa perusahaan sebab terdapat beberapa unsur seperti penumpukan persediaan yang dapat meningkatkan biaya serta menunjukkan penjualan yang sedang mengalami penurunan. Terlebih hal ini didukung dengan adanya analisis terhadap aset perusahaan yang menunjukkan bahwa BULOG belum mampu menggunakan asetnya secara optimal. BULOG memiliki berbagai aset potensial yang dapat dikomersialkan seperti gedung perkantoran, gudang-gudang, serta networking yang jika tidak dioptimalkan justru akan menjadi kendala bagi Perum BULOG sendiri. Hal ini menunjukkan potensi komersialisasi 
ANALISIS KINERJA KEUANGAN PERUM BULOG SELAMA PENUGASAN PUBLIC SERVICE OBLIGATION TAHUN 2015 $-2018$

I Putu Restu Krisnawan ${ }^{1}$ dan Ambang Aries Yudanto ${ }^{2}$

sebagai wujud pemanfaatan aset yang masih rendah dan belum dimanfaatkan secara efisien (Suswono et al, 2009).

\section{c. Return on Equity (ROE)}

Data pergerakan ROE dari Perum BULOG selama periode tahun analisis dapat diamati pada grafik berikut ini.

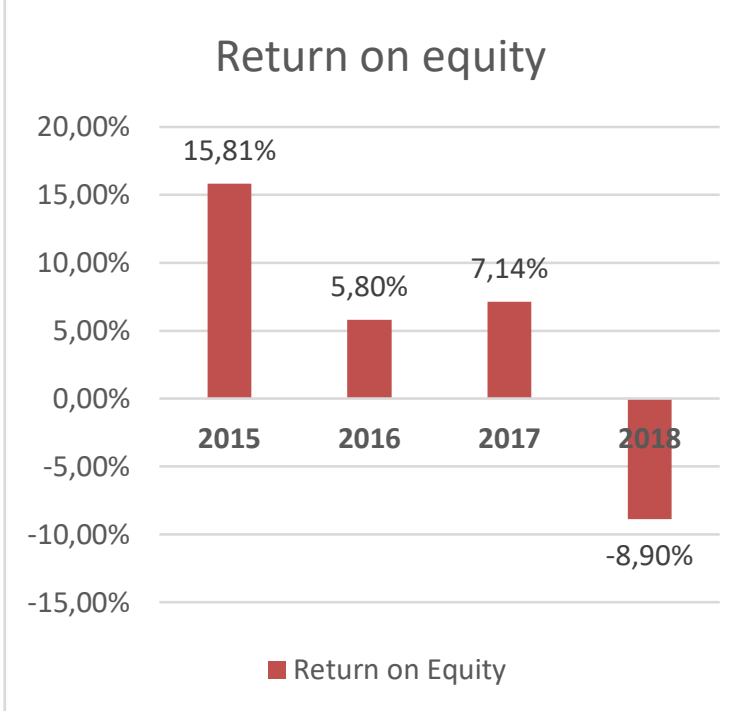

\section{Gambar 15 Grafik Pergerakan Return on Equity Sumber: Data diolah oleh Penulis}

Hasil perhitungan ROE pada Perum BULOG tidak jauh berbeda dengan ROA. Penurunan terjadi pada tahun 2016 dikarenakan penurunan pada laba bersih walaupun ekuitas perusahaan meningkat sebesar $42,83 \%$ dari tahun 2015. Pada tahun 2018, rasio ini juga menunjukkan hasil negatif sebesar $-8,90 \%$ yang disebabkan oleh penurunan laba bersih dan penurunan ekuitas sebesar 7,28\%.

Hasil perhitungan rasio ini menunjukkan bahwa tingkat pengembalian terhadap ekuitas, khususnya modal yang diberikan pemerintah, pada Perum BULOG menunjukkan hasil yang tidak stabil dan cenderung menunjukkan trend penurunan pada tahun analisis. Hal tersebut dikarenakan adanya penurunan penjualan pada tahun analisis dan disertai dengan besarnya beban keuangan yang dimiliki oleh Perum BULOG.

\section{SIMPULAN DAN SARAN Simpulan}

Berdasarkan hasil penelitian dan pembahasan, dapat disimpulkan bahwa pemberian PSO pada tahun 2015 hingga tahun 2018 berdampak pada kinerja perusahaan, berdasarkan perhitungan rasio keuangan, kinerja Perum BULOG mengalami penurunan baik dari penjualan maupun struktur modal. Rasio likuiditas berada dalam kondisi baik namun perlu perhatian lebih pada aspek persediaan. Rasio solvabilitas menunjukkan pergerakan yang baik hingga tahun 2017 dan menurun pada tahun 2018. Rasio aktivitas sangat fluktuatif dan dipengaruhi oleh PSO yang diberikan. Rasio profitabilitas menunjukkan trend penurunan yang didorong oleh penurunan aspek penyaluran pada PSO.

Pemberian penugasan kepada Perum BULOG tidak serta merta meningkatkan kinerja perusahaan. PSO yang diberikan menyebabkan BULOG harus melakukan penyerapan melalui proses pengadaan dengan menggunakan pinjaman dari perbankan. Selain itu, adanya regulasi tertentu dapat mempengaruhi penugasan yang menyebabkan penurunan pada aspek penjualan, seperti perubahan pola Rastra menjadi BPNT. Oleh karenanya, Perum BULOG tidak dapa menggantungkan proses bisnisnya hanya pada segmen PSO dan harus diimbangi dengan pengembangan pada segmen komersial. Namun, pengembangan ini juga menuntut perusahaan untuk melakukan pinjaman sebagai dasar kebutuhan dana. Hal tersebut berdampak pada meningkatnya liabilitas jangka pendek sehingga mempengaruhi kondisi keuangan secara signifikan.

\section{Saran}

Analisis kinerja keuangan selama periode tahun 2015 hingga 2018 ini dapat digunakan sebagai bahan pertimbangan pemerintah dalam memberikan PSO kepada Perum BULOG khususnya agar tercipta pengelolaan BUMN yang baik selama pelaksanaan kewajiban pelayanan publik. Hasil dari penelitian ini juga dapat digunakan sebagai bahan pertimbangan manajemen perusahaan Perum BULOG khususnya keputusan keuangan agar tercipta kinerja perusahaan yang lebih baik saat menerima PSO dari pemerintah.

\section{DAFTAR PUSTAKA}

Acharya, Viral V. and Afonso, Gara and Kovner, A. (2017). How do global banks scramble for liquidity? Evidence from the asset-backed commercial paper freeze of 2007. Journal of Financial Intermediation, 30, 1-34.

Andriyani, Ima. 2015. Pengaruh Rasio Keuangan terhadap Pertumbuhan Laba pada Perusahaan Pertambangan yang Terdaftar di Bursa Efek Indonesia. Jurnal Manajemen dan Bisnis Sriwijaya. Vol. 13 No. 3 September 2015.

Arikunto, S. 2006. Metode Penelitian Kualitatif. Jakarta: Bumi Aksara.

Avramov, D., Chordia, T., \& Goyal, A. (2006). Liquidity and autocorrelations in individual stock returns. The Journal of Finance, 61(5), 2365-2394.

Bolek, M., \& Wolski, R. (2012). Profitability or Liquidity: Influencing the Market Value-The Case of Poland. International Journal of 
Economics and Finance, 4(9). https://doi.org/10.5539/ijef.v4n9p182

Boudoukh, J., \& Whitelaw, R. F. (1993). Liquidity as a choice variable: A lesson from the Japanese government bond market. The Review of Financial Studies, 6(2), 265-292.

BULOG. 2017. "Demi Infrastruktur Pascapanen, BULOG Investasi Rp2,3 Triliun." Tersedia pada halaman Bulog.co.id. Diakses pada 30 Mei 2020.

BULOG. 2019. "BULOG dalam Pilar Ketahanan Pangan". Tersedia pada halaman Bulog.co.id. Diakses pada 1 Juni 2020.

Harahap, Sofyan Syafri. 2009. Teori Kritis Laporan Keuangan. Jakarta: Bumi Aksara.

Ingan, Novel, LCA Robin Jonathan, dan Danna Solihin. 2020. Analisis Kinerja Keuangan Pada Perum BULOG Sub Divisi Regional Samarinda (Periode 2016-2018). Jurnal Ekonomia Vol 9, No 1 Tahun 2020.

Kasmir. 2003. Studi Kelayakan Bisnis: Edisi Revisi. Jakarta: Kencana Prenada Group.

Kasmir. 2012. Analisis Laporan Keuangan. Jakarta: Penerbit Rajawali Pers.

Nazir, Mohammad. 1999. Metode Penelitian, Cetakan Ketiga. Jakarta: Ghalia Indonesia.

Noreen, E. W., Brewer, P. C., \& Garrison, R. H. (2011). Managerial Accounting for Managers. McGraw-Hill Irwin.

Nugraha, Bagas Haryo. 2019. Analisis Rasio Keuangan Berdasarkan Rasio Likuiditas, Solvabilitas dan Profitabilitas Pada BULOG Divisi Regional Jawa Timur. Tugas Akhir: Program Pendidikan Diploma 3 Prodi Akuntansi STIE Perbanas. Surabaya.

Olaganju, A \& Adeyanju, D \& Olabode, S. (2011). Liquidity Management and Commercial Banks' Profitability in Nigeria. Research Journal of Finance and Accounting, 2(7), 24-39.

Peraturan Pemerintah Republik Indonesia Nomor 13 Tahun 2016 tentang Perusahaan Umum (Perum) Bulog.

Instruksi Presiden Republik Indonesia Nomor 5 Tahun 2015 tentang Kebijakan Pengadaan Gabah/Beras Dan Penyaluran Beras Oleh Pemerintah.

Peraturan Presiden Republik Indonesia Nomor 48 Tahun 2016 tentang Penugasan Kepada Perusahaan Umum (Perum) Bulog Dalam Rangka Ketahanan Pangan Nasional.

Peraturan Presiden Republik Indonesia Nomor 20 Tahun 2017 tentang Perubahan Perubahan atas Perpres No. 48 Tahun 2016 tentang Penugasan kepada Perusahaan Umum (Perum) BULOG dalam rangka Ketahanan Pangan Nasional.

Rashid, C. A. (2018). Efficiency of Financial Ratios Analysis for Evaluating Companies' Liquidity. International Journal of Social Sciences \& Educational Studies, 4(4). https://doi.org/10.23918/ijsses.v4i4p110

Ristianto, Christoforus. 2019. “Ombudsman Sarankan BULOG Dibubarkan Karena Terus Merugi". Tersedia pada halaman kompas.com. Diakses pada 29 Mei 2020.

Sugiyono. 2013. Cara Mudah Menyusun: Skripsi, Tesis, dan Disertasi. Bandung: Alfabeta.

Sugiyono. 2015. Metode Penelitian Kombinasi (Mixed Method). Bandung: Alfabeta.

Suswono, Daryanto, Arief, dkk. 2009. Strategi Peningkatan Daya Saing Perum BULOG. Jurnal Manajemen dan Agribisnis. Vol. 6 No. 2 Oktober 2009.

Thomas, Vincent Fabian. 2019. “Kemenkeu Sebut BULOG Terancam Bangkrut, Utangnya Capai Rp28 Triliun". Tersedia pada halaman tirto.id. Diakses pada 30 Mei 2020.

Undang-undang Nomor 18 Tahun 2012 tentang Pangan. 